\title{
Studies in Oberonia 10. A re-evaluation of Oberonia brachystachys and 0 . subligaculifera (Orchidaceae: Malaxideae) and their synonyms
}

\author{
Geiger D.L. ${ }^{1 *}$, Sulaiman M. ${ }^{2}$ \& C. Murugan² \\ 'Santa Barbara Museum of Natural History, 2559 Puesta del Sol, Santa Barbara, California - 93105, USA \\ 'Visiting Research Scholar, Huntington Library, Art, Museum and Botanical Gardens - Botany Division, 1151 Oxford Street, \\ San Marino, California - 91108, USA \\ ${ }^{2}$ Botanical Survey of India, Southern Regional Circle, Coimbatore, Tamil Nadu - 641 003, India \\ *E-mail: dgeiger@sbnature2.org
}

\begin{abstract}
The following synonyms are introduced or confirmed for Oberonia brachystachys Lindl.: O. recurva Lindl., O. setifera Lindl., O. demissa Lindl., O. gardneriana Thwaites, O. parvula King \& Pantl. [including $O$. myriantha var. parvula (King \& Pantl.) Tang \& Wang], O. croftiana King \& Pantl. (second-step lectotypification herein), O. lingmalensis Blatt. \& McCann [including O. recurva var. lingmalensis (Blatt. \& McCann) Santapau \& Kapadia], and O. brachyphylla Blatt. \& McCann (lectotypified herein). Oberonia subligaculifera J.J.Sm. has the following new or confirmed synonyms: $O$. bambusicola Kerr, O. evrardii Gagnep., O. kanburiensis Seidenf., O. arunachalensis A.N.Rao, O. raoi L.R.Shakya \& R.P.Chaudhary, and O. kamlangensis A.N.Rao. Both species are re-described taking into account their intraspecific variability and ecological data are provided. Oberonia brachystachys with unjointed leaves is illustrated with light and scanning electron microscope images.
\end{abstract}

Keywords: Lectotypification, Morphological characters, Nomenclature, Variability.

\section{Introduction}

Oberonia Lindl. is an old-world genus of mostly epiphytic herbs comprising 300 species (Mabberley, 2018), which is likely an overestimate given the numerous new synonyms uncovered in recent years (Geiger, 2016, 2019, 2020, 2021, unpubl. data; Gogoi \& Yonzone, 2016; Bunpha et al., 2019; Geiger et al., 2020). Geiger et al. (2020) estimated

Received: 23.11.2020; Revised \& Accepted: 16.09.2021

Published Online: 16.10.2021 that the genus is over-described by approximately one third, which would put the true species number rather at approximately 150-200 worldwide (Pridgeon et al., 2005).

In India, 61 species have been reported in the genus (Ansari \& Balakrishnan, 1990; Kumar \& Manilal, 1994, 2004; Misra, 2007; Narayanan et al., 2010, 2013; Chowlu et al., 2015; Chowlu \& Rab, 2017; Prasad et al., 2018; Kaliamoorthy \& Saravanan, 2019). That number of species is equally an overestimate due to a number of synonyms uncovered in recent years (Geiger, 2016, 2019, 2020; Gogoi \& Yonzone, 2016; Bunpha et al., 2019): O. anthropophora Lindl. (+ O. falcata King \& Pantl.), O. bicornis Lindl. (+ O. tenuis Lindl.), O. brunoniana Wight (+ O. lindleyana Wight, O. saintberchmansii Kad.V.George \& J.Mathew, O. santapani Kapadia in Santapau \& Kapadia, O. wallichiii Hook.f.), O. caulescens Lindl. (+ O. katakiana A.N.Rao), O. langbianensis Gagnep. (+ O. sulcata Joseph \& Sud.Chowdhury), O. maxima Parish ex Hook.f. (+ O. integerrima Guillaumin, O. orbicularis Hook.f.), O. mucronata (D.Don) Ormerod \& Seidenf. (+ O. manipurensis Chowlu, Y.N.Devi, A.N.Rao, N.Angela, H.B.Sharma \& Akimpou), O. rufilabris Lindl. (+ O. nepalensis L.R.Shakya \& R.P.Chaudhary, O. pantlingiana L.R.Shakya \& R.P.Chaudhary). It is likely that additional names will be placed in synonymy.

A species of Oberonia collected during botanical explorations in Kerala (2019-2020), in the Aralam 
Wildlife Sanctuary, Kannur, flowered in the Glass House at the Botanical Survey of India, Southern Regional Centre, Coimbatore. It was identified as O. brachystachys Lindl. based on herbarium records at CAL and MH, and literature (Seidenfaden, 1968; Ansari \& Balakrishnan, 1990; Misra, 2007). The specimen was initially considered a range extension of $O$. brachystachys, but provided the impetus for a critical taxonomic analysis resulting in the unravelling of the convoluted taxonomy.

\section{Materials and Methods}

Taxonomic assessments were made based on available information from primary and secondary literature, herbarium holdings (BM, CAL, E, F, K, MEL, MO, OHT [Orchid Herbarium, Tipi, Arunachal Pradesh, India], P, US, W, WU), and on-line herbarium databases (AMES, BR, L; herbarium acronyms as per Thiers, continuously updated). The $\mathrm{K}$ specimens without barcode are held in the Lindley herbarium at K. DLG numbers refer to the Daniel L. Geiger living collection in greenhouse in Santa Barbara, California. HOAG numbers refer to the Geiger personal herbarium.

The type designation follows the modern interpretation of McNeill (2014, 2015). Unless a holotype is designated explicitly with repository in the protologue, or the description is explicitly based on a single specimen, then all specimens from the cited gathering(s) are syntypes.

Ecological data was gathered from the literature and indications on herbarium specimens, with all herbariums specimens being considered equivalent to one literature reference. The percentage of observations refer to the frequency a particular flowering month or elevation (to nearest $100 \mathrm{~m}$ ) has been given by each of the cited sources. Accordingly, 100\% means that all cited sources agree, while $50 \%$ indicates that only half of the sources give that particular flowering month or elevation.

Z-stack photography was carried out on a Discovery V20 stereomicroscope with plan apochromatic lenses and motorized focus (Zeiss, Germany). Image stacks were captured with an Axiocam HRc camera (Zeiss, Germany) and processed in ZereneStacker (Zerene Systems LLC, 2009-2021). Flowers and floral parts were also imaged with a SMZ1500 stereomicroscope (Nikon, Japan). For scanning electron microscopy (SEM), flowers were preserved in 95\% ethanol, further dehydrated through three changes of 100\% ethanol, critical point dried in a $815 \mathrm{~A}$ (Tousimis, USA) using standard settings, then mounted on double sided carbon tabs (Ted Pella, USA), sputter coated with gold, and imaged in an EVO 40 XVP (Zeiss, USA) using the VPSE detector in variable pressure (30 $\mathrm{Pa})$ at $20 \mathrm{kV}$ and probe currents ranging from 30 500 pA depending upon working distance and magnification. Illustrations were processed in AffinityPhoto 1.10.1 (Serif, 2021).

\section{Taxonomic Treatment}

Oberonia brachystachys Lindl., Sert. Orchid. t. 8 B. 1838. Syntypes: BURMESE EMPIRE, s.loc., s.d., Griffith 697 (K!), Griffith 778 (K!; P [P00404973]!); possible syntype: Griffith s.n. (K!).

Oberonia recurva Lindl., Edwards's Bot. Reg. 25 (Misc.): 14. 1839. Lectotype (inadvertent designation by Ansari \& Balakrishnan, 1990: 38 by reference to "Type ... (K)"): INDIA, Maharashtra, Bombay, s.d., Loddiges s.n. (K!), syn. nov.

Oberonia setifera Lindl., Fol. Orchid. 8: 3. 1859. Lectotype (inadvertent designation by Ansari \& Balakrishnan, 1990: 38 by reference to "Type ... (K)"): INDIA, Maharashtra, South Koncan (= Koukan, Mumbai), s.d., Dalzell ex Stocks 38 (K!), syn. nov.

Oberonia demissa Lindl., Fol. Orchid. 8: 4. 1859. Lectotype (inadvertent designation by Seidenfaden, 1978: 37 by reference to "K, type"): INDIA, Sikkim, Terai, J.D. Hooker 121 (K!).

Oberonia gardneriana Thwaites, Enum. Pl. Zeyl. 296. 1861. Syntype: SRI LANKA, Ambagamowa district, s.d., Gardner s.n. [Thwaites] CP 593 (PDA n.v. fide Jayaweera, 1981: see Notes). syn. nov. 
Oberonia parvula King \& Pantl., J. Asiat. Soc. Bengal, Pt. 2, Nat. Hist. 64: 330. 1896. Lectotype (inadvertent designation by Ansari \& Balakrishnan, 1990: by reference to "Type: Pantling 203 ... (CAL)"]: INDIA, Sikkim, valley of Teesta, $1500 \mathrm{ft}$, R. Pantling 203 (CAL [CAL0000000040]!); isolecto AMES/HUH [HUH00102050]!, BM [BM000088303]!, G n.v:: fide Seidenfaden, 1968, K [K000387743]!, P [P0040885]!). syn. nov.

Oberonia croftiana King \& Pantl., Ann. Roy. Bot. Gard. (Calcutta) 8: 7, pl. 6A. 1898. Lectotype (firststep inadvertent designation by Ansari \& Balakrishnan, 1990: 38 by reference to "Type: ...(CAL)"; second-step designation here): INDIA, Sikkim, Tropical Valleys, October 1893, Pantling 254 (CAL [CAL0000000048: Tropical Valleys]!), isolectotypes (CAL [CAL0000000049]!; AMES [HUH 00101950]!, BM [BM000088297]!, BR [BR0000006572181]!, K [K000387742]!, P [P00404879]!). Residual syntypes: INDIA, Sikkim, Dikkeling [= Dikling], Pantling 254 L [L0061772]!; W [W5951]!); Locality unknown (G n.v.: fide Seidenfaden, 1968). syn. nov.

Oberonia lingmalensis Blatter \& McCann, J. Bombay Nat. Hist. Soc. 35: 255. 1931. O. recurva Lindl. var. lingmalensis (Blatt. \& McCann) Santapau \& Kapadia, J. Bombay Nat. Hist. Soc. 57: 259. 1960. Holotype: INDIA, Maharashtra, Western Ghats, Lingmala, near Yenna waterfall, a few miles from Mahableshwar [= Mahabaleshwar] on road to Panchgani, Blatter \& Hallberg P 1681 (BLAT n.v.). Paratypes: INDIA, Karnataka, North Kanara, in forests, Bell 5406 (repository unknown). Maharashtra, Kamelgad, below Fort (Fernandez I). Sedgwick 7755, 4626 (repository unknown). Maharashtra, Konkan, Thana [= Thane] forest, Bell 3972 (repository unknown). syn. nov.

Oberonia brachyphylla Blatt. \& McCann, J. Bombay Nat. Hist. Soc. 35: 257. 1931. Lectotype (designated here): INDIA, Karnataka, North Kanara, Blatter \& McCann (1931: pl. 2!). syn. nov.

Figs. 1-5

Small erect or pendulous epiphytic herbs, usually 4-6 leaves, unjointed, forming stemless fan. Leaves variable in length, shape, typically elongated ovate acute, occasionally squat ovate acute, typically 2-6 $\mathrm{cm}$ long, 0.6-1.2 cm wide. Roots thin, fibrous, unbranched. Inflorescence typically $5-7 \mathrm{~cm}$ long, typically $1.5-3 \times$ as long as leaves. Scape short, rachis longitudinally grooved, flowers variously arranged from distinct whorls, to in spiral, or scattered. Flowers $0.75-1.5 \times 1-1.75 \mathrm{~mm}$, average $\sim 1.5 \times 1.5$ $\mathrm{mm}$, green, yellow, brown, orange, sometimes two-coloured with lip orange to brownish red, reminder greenish. Bract acuminate acute, margin irregular, about as long as flower. Pedicelled ovary round, $1 \mathrm{~mm}$ long. Orientation of all tepals flat or somewhat forward. Sepals broad, oval, acute. Petals oblong, obtuse, erose to dentate. Lip typically four lobed, lateral lobes square or trapezoidal with tips towards epichile, margin typically erose to dentate, occasionally irregular; mesochile more or less constricted, entire; typically two distinct (occasionally indistinct) epichile lobes, truncated, rounded or falcate towards midline, margins dentate, erose, or occasionally irregular, disc indistinct, sac minute depression to large cavity.

Flowering: Flowering throughout the year with peaks in February and October (Fig. 5a). The break in June is considered a data artifact.

Habitat: Erect or pendulous epiphyte on branches of shrubs and trees in tropical wet or dry evergreen forest to subtropical montane forest, in association with Dendrobium ovatum (L.) Kraenzl. (Orchidaceae), on Carissa congesta L. (Apocynaceae), Anacardium occidentale L., Holigarna grahamii (Wight) Kurz, Mangifera indica L. (all Anacardiaceae), Heterophragma quadriloculare (Roxb.) K.Schum. (Bignoniaceae), Garcinia indica Choisy (Clusiaceae), Elaeocarpus serratus L. (Eleocarpaceae), Euphorbia nerifolia L. (Euphorbiaceae), Erythrina suberosa Roxb., Bauhinia racemosa Lam. (all Fabaceae), Memecylon umbellatum Burm.f. (Melastomataceae), Tectona grandis L.f. (Lamiaceae), Careya arborea Roxb. (Lecythidaceae), Bombax ceiba L. (Malvaceae), Ficus arnottiana (Miq.) Miq., F. benghalensis L., F. racemosa L., Artocarpus heterophyllus Lam. (all Moraceae), 
a
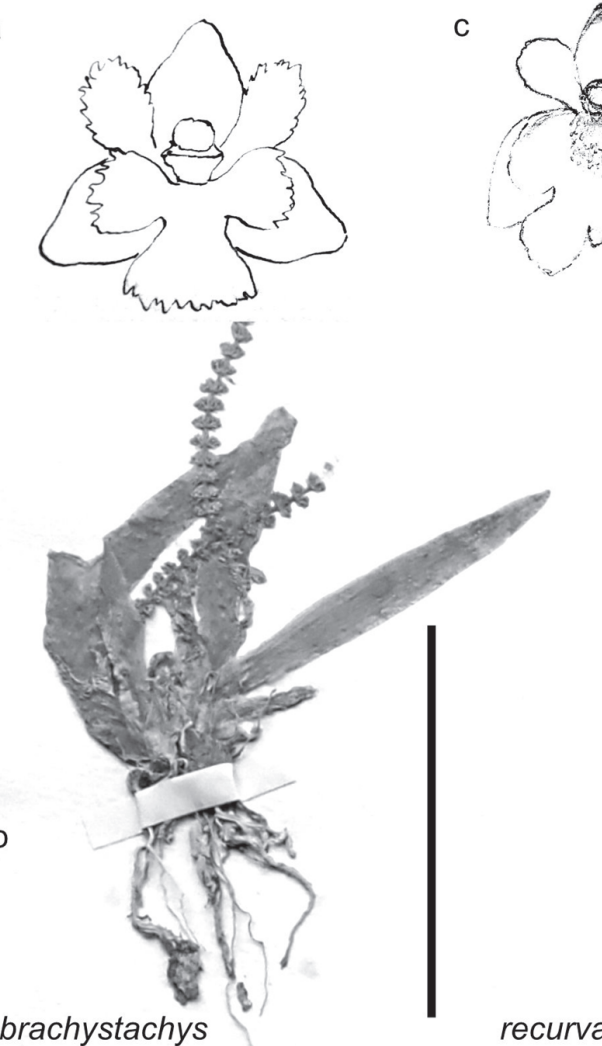

c

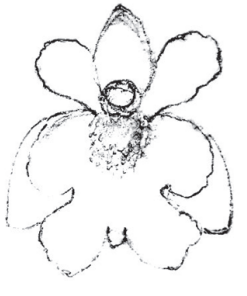

d
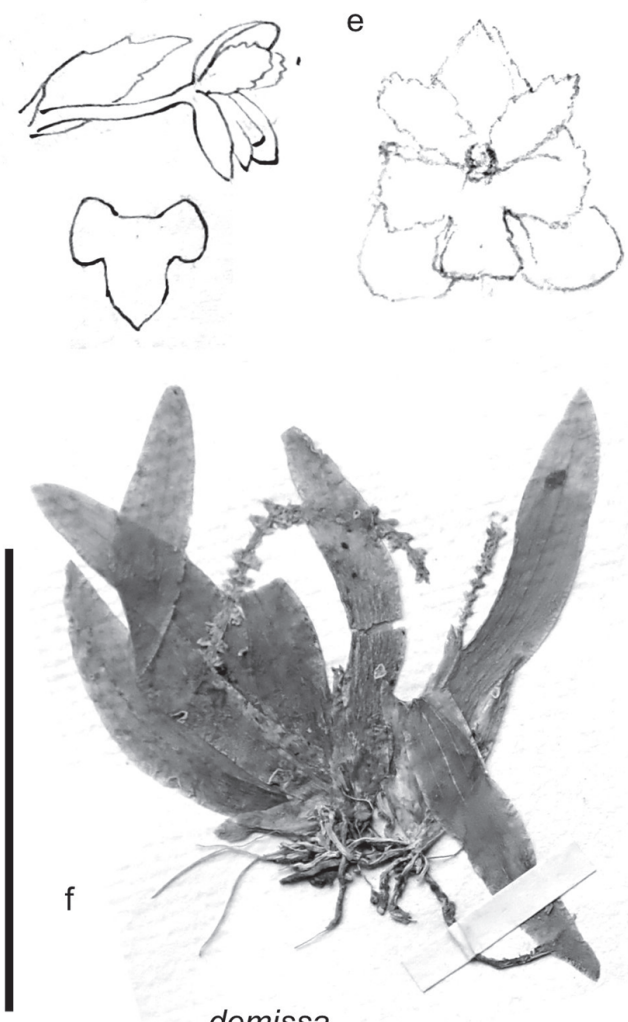

demissa

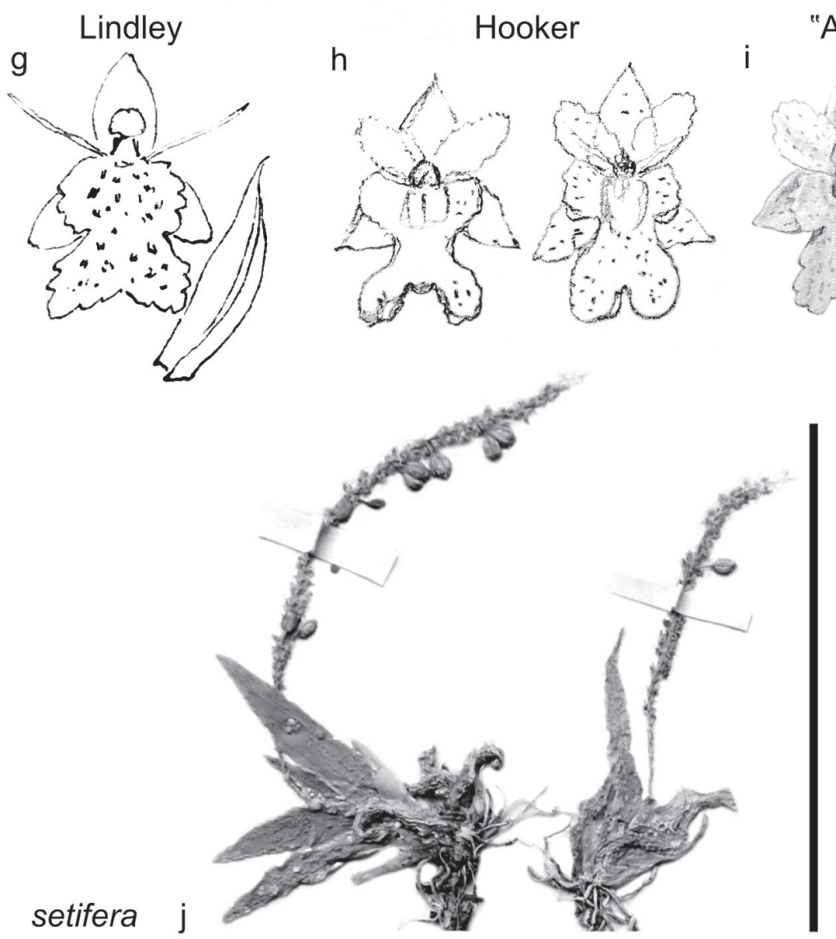

"A.S." ?
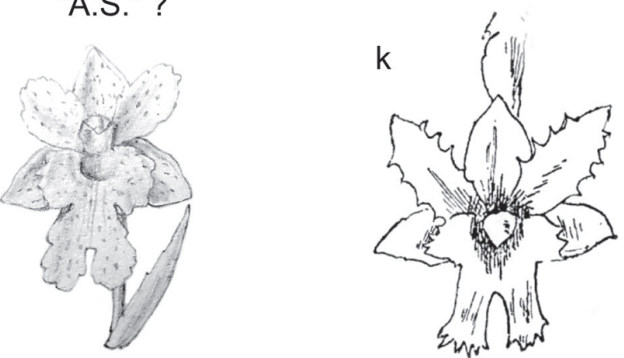

brachyphylla

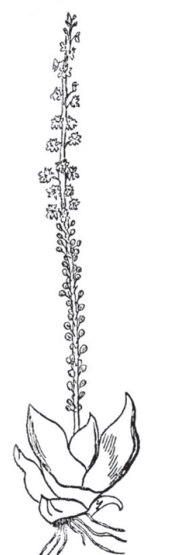

Fig. 1. Photographic images and drawings of Oberonia spp.: a \& b. O. brachystachys Lindl., K syntype sheet; the two gatherings Griffith 697 and Griffith 778 are not individually identified on sheet; a. Drawing of flower; b. Habit of one of three specimens; c. Oberonia recurva Lindl., drawing of flower on lectotype sheet Loddiges S.n (K); d-f. Oberonia demissa Lindl., Hooker f. 121 (lectotype K); d. Drawing by unknown person; e. Drawing by J.D. Hooker; f. Specimen; g-j. Oberonia setifera Lindl., Dalzell ex Stocks 38 (lectotype K); g. Drawing by J. Lindley; h. Drawings by J.D. Hooker; i. Drawing by "A.S." [?]; j. Specimen; k \& I. Lectotype of O. brachyphylla Blatter \& McCann (1931: pl. 2); k. Flower; I. Habit. Scale bars b,f,j $=5 \mathrm{~cm}$. (photos a-j by D. L. Geiger; k,l from Blatter \& McCann [1931: pl. 2]). 


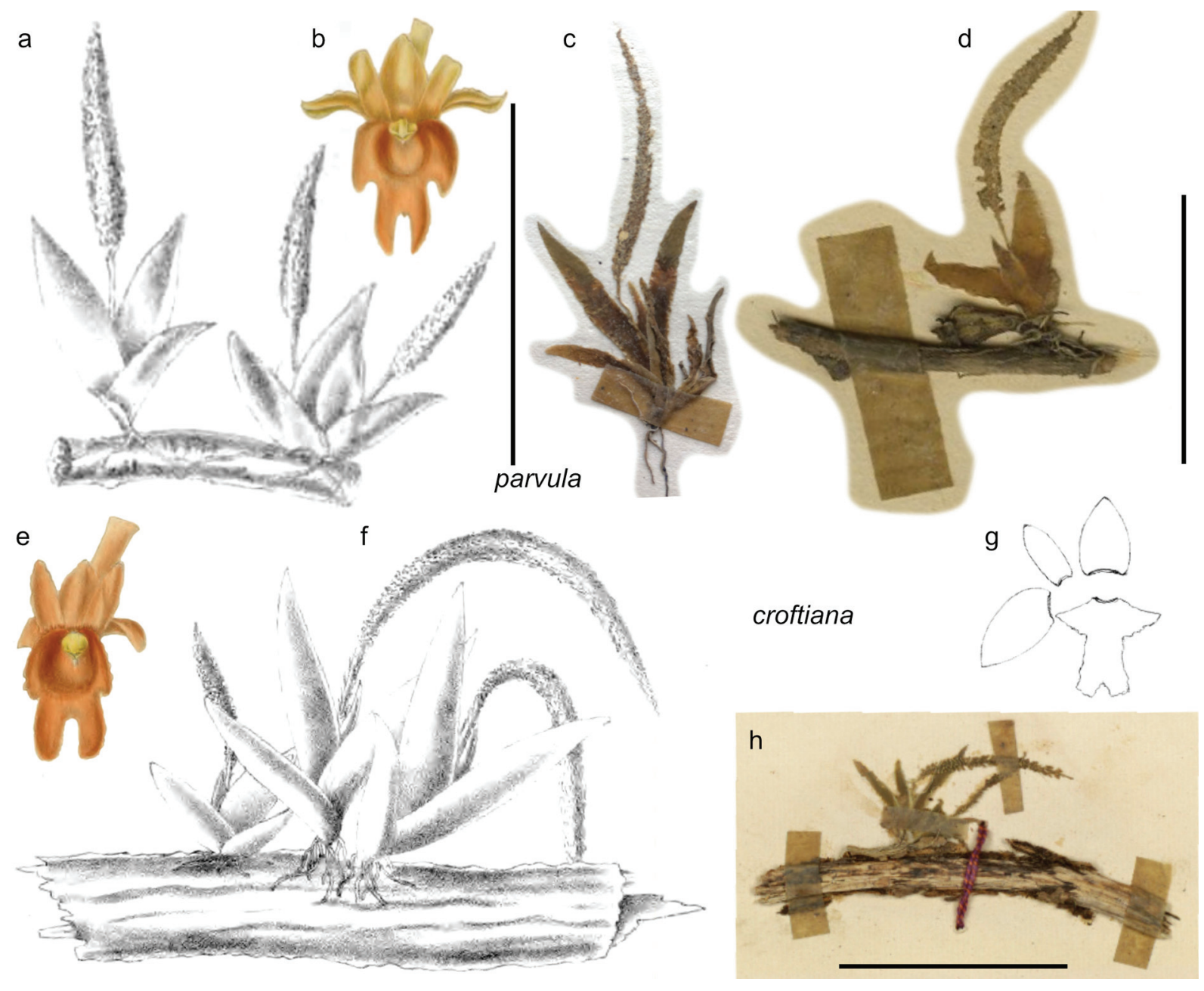

Fig. 2. Photographic images and drawings of Oberonia spp. a. Drawing of habit of O. parvula King \& Pantl. from King and Pantling (1898: pl. 6B); b. Flower of O. parvula from King and Pantling (1898: pl. 6B); c. Likely original material of O. parvula, Pantling 203 (K [K000387743]); d. Likely original material of O. parvula, Pantling 203 (AMES [HUH00102050]); e. Flower of O. croftiana King \& Pantl. from King and Pantling (1898: pl. 6A); f. Drawing of habit of 0. croftiana from King and Pantling (1898: pl. 6A); g. Drawing of flower on 0. croftiana isolectotype sheet Pantling 254 (P [P00404879]). Floral parts digitally rearranged to natural positions; h. Isolectotype Pantling 254 (L [L0061772]). Scale bars $c, h=5 \mathrm{~cm} ; \mathrm{d}=2.5 \mathrm{~cm}$. (a,b,d-h from cited publication under fair use provision of copyright law. Photo c by D.L. Geiger).

Canthium dicoccum Gaertn., Catunaregam spinosa (Thunb.) Tirveng., Ixora brachiata Roxb., Randia brandisii Gamble (all Rubiaceae), Flacourtia indica (Brum.f.) Merr. (Salicaceae), Turpinia malabarica Gamble (Staphyleaceae). 0-2400 m, predominantly below $1800 \mathrm{~m}$ (Fig. 5b).

Distribution: Bhutan, China (Guangxi?: see Notes), India, Malaya, Myanmar, Nepal, Sri Lanka, Thailand (Anonymous, n.d.b; Hooker, 1888; Cooke, 1907; Brühl, 1926; Blatter \& McCann, 1931; Mitra, 1958; Seidenfaden \& Smitinand, 1959; Santapau, 1967; Seidenfaden, 1978; Pradhan, 1979; Bose \& Bhattacherjii, 1980;
Jayaweera, 1981; Banerji \& Pradhan, 1984; Ansari \& Balakrishnan, 1990; Naithani, 1990; Seidenfaden \& Wood, 1992; Turner, 1995; Sakkar, 1995b; Srivastava, 1996; Bose et al., 1999; Kress et al., 2003; Lucksom, 2007; Misra, 2007; Raskoti, 2009; Chen et al., 2009 Cerejo-Shivkar \& Shinde, 2015; Jalal, 2018; Singh et al., 2019: see Notes). Some of the eastern distributional records (Malaya, Thailand) may be due to confusion of $O$. brachystachys with $O$. subligaculifera. The distribution based on type material of the O. brachystachys and its synonyms extends from India, Sri Lanka, to Myanmar. 


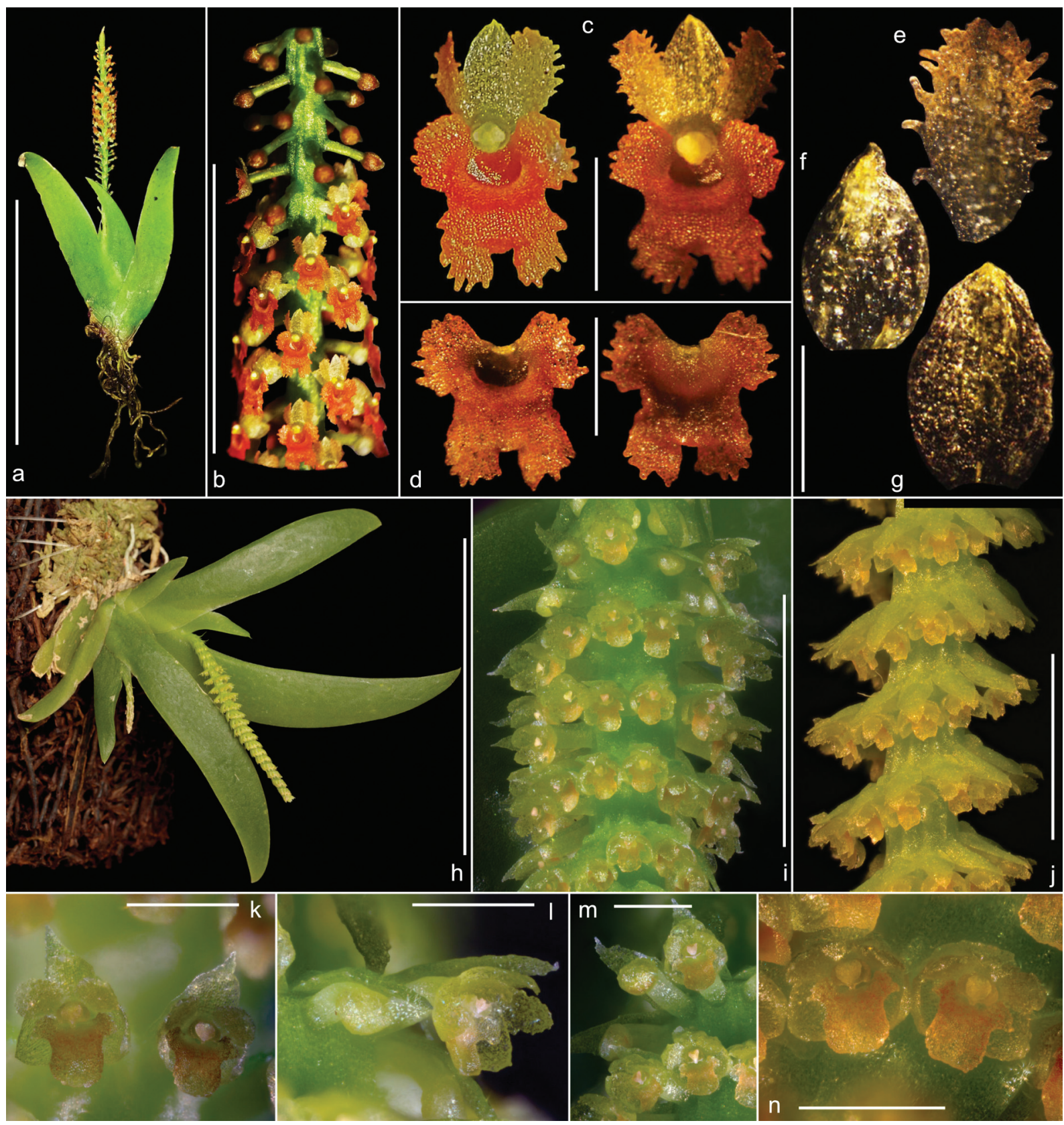

Fig. 3. Photographic images of living plants of Oberonia brachystachys Lindl.: a. Habit; b. Portion of inflorescence; c. Flowers; d. Lip, front (left) and back (right) sides; e. Petal; f. Lateral sepal; g. Median sepal; h. Habit (DLG521); i. Portion of inflorescence, z-stack of 42 images (DLG521); j. Portion of inflorescence, z-stack of 10 images (DLG521); k-n. Individual flowers (DLG521): k. Z-stack of 43 images (DLG522); I. Z-stack of 38 images; $m$. Z-stack of 36 images; $n$. Z-stack of 53 images. Scale bars: $a, h=5 \mathrm{~cm} ; b=1 \mathrm{~cm} ; c, d, k-n=1 \mathrm{~mm} ; e-g=0.5$ mm; i,j = 5 mm (photos a-g by M. Sulaiman, from M. Sulaiman 145464, MH [MH00257633]; h-n by D. L. Geiger).

Specimens examined: INDIA, Kerala, Kannur, Aralam Wildlife Sanctuary, N 11ํ5ㄴ 5122 , E $75^{\circ} 4824522 \pm 110 \mathrm{~m}, 29.12 .2019$, M. Sulaiman $145464 \mathrm{MH}$ [MH00257633]. Maharastra, Western Ghats, Lingmala near Mahabaleshwar, Townsend 73/10 (K). Sikkim, valley of theTeesta, 1898, $R$. Pantling 238 (BM [BM000088265],CAL
[CAL0000077889], MEL [MEL2409511A], MH [MH00042702], P [P00404975], P[P00404976], US [US00241398], WU).

Notes: Oberonia brachystachys is characterized by the relatively small size of the plant, unjointed leaves, bracts that are about as long as the pedicellate ovary, 

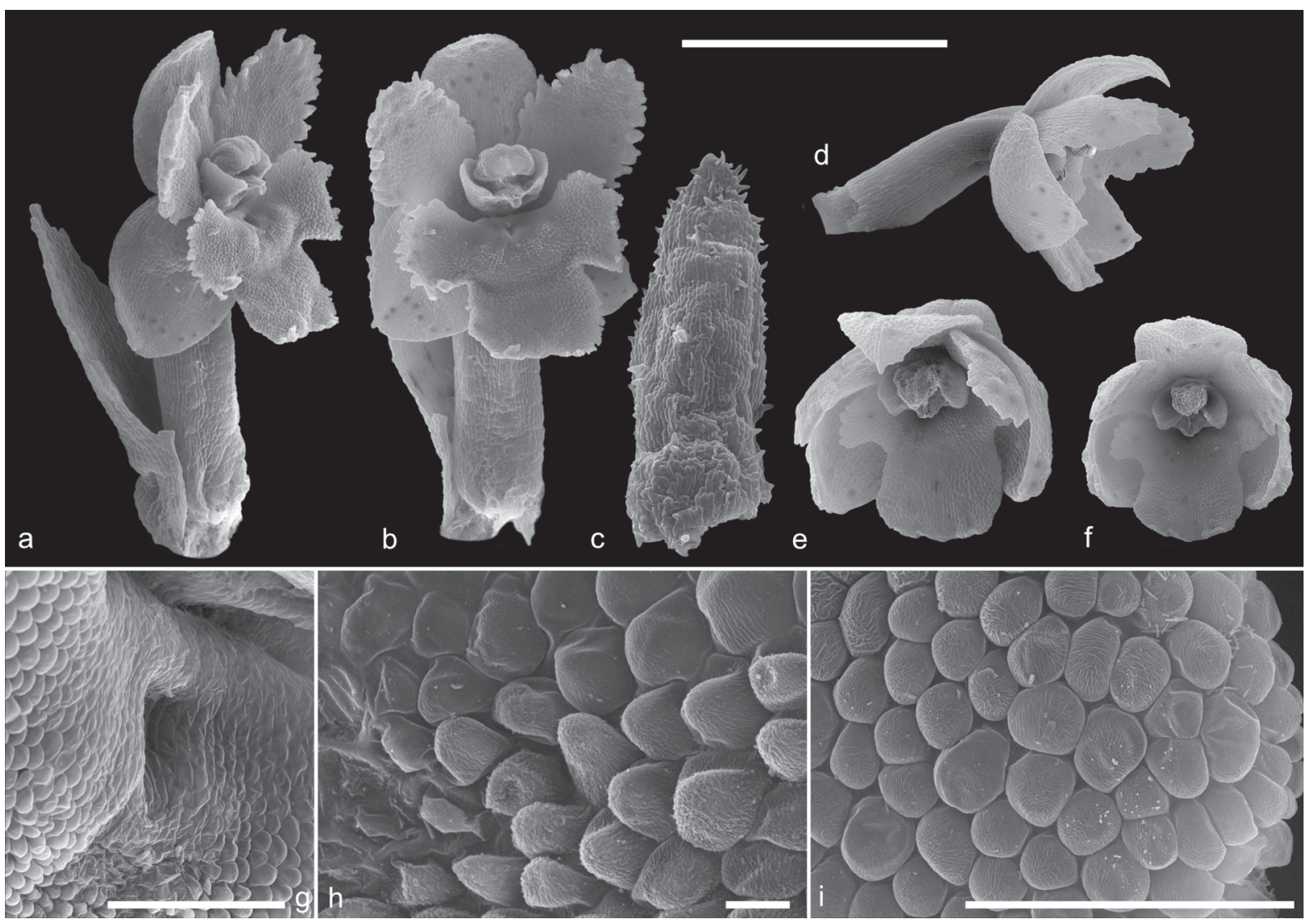

Fig. 4. SEM images of Oberonia brachystachys Lindl.: a. Flower-oblique view with floral bract; $\mathbf{b}, \mathbf{e}$ \& f. Flower-frontal view; $\mathbf{c}$. Floral bract; $\mathbf{d}$. Flower-lateral view; g. Disc with sac; h. Microrugulate surface morphology of conical cells surrounding disc; i. Microrugulate surface sculpture of pneumate epichile cells. Scale bar for $a-f=1 \mathrm{~mm} ; \mathrm{g}, \mathrm{i}=100 \mu \mathrm{m} ; \mathrm{h}=10 \mu \mathrm{m} ;(\mathrm{a}-\mathrm{c}, \mathrm{g}-\mathrm{i}$. K [K59697], India; d-f. DLG521/H0AG78, in cultivation; images by D.L. Geiger).

small flowers $(0.75-1.5 \times 1.0-1.75 \mathrm{~mm}$ according to protologues, average $\sim 1.5 \times 1.5 \mathrm{~mm}$ ), strongly erose, ovate petals, and a variable lip typically with quadrate lateral lobes with strongly erose margins, a more or less constricted and entire mesochile, and more or less developed diverging epichile lobes with strongly erose margins.

Oberonia brachystachys has two recognized synonyms, O. demissa and O. bambusicola Kerr (Seidenfaden \& Smitinand, 1964; Bunpha et al., 2019). Oberonia demissa is here confirmed as synonym of O. brachystachys, while O. bambusicola is synonymized under O. subligaculifera (see below). Below we discuss each of the synonyms in greater detail.

Three main forms have been recognized, distinguished by the unnotched epichile of $O$. brachystachys vs. deeply incised epichile and more or less rectangular epichile lobes of O. recurva vs. lip with falcate epichile lobes of $O$. parvula. Those three morphs represent points along a spectrum of continuous variability. The three lips illustrated by Ansari and Balakrishnan (1990: fig. 36) under O. recurva show variation from shallow notch to deep incision, clearly documenting the intraspecific variability. Illustrations of O. brachystachys (Fig. 1) and its synonyms O. parvula, O. croftiana (Fig. 2) show intermediate character states of the epichile lobes quadrate, rounded, and falcate.

Differences in drawings from the same plant as demonstrated here with O. setifera (Fig. 1g-i) further caution the reliance on minute details in drawings. Floral variability has been confirmed with molecular data in O. equitans (G.Forst.) Mutel by Geiger et al. (2020) is also evident in the work of $\mathrm{Li}$ et al. (2016) (see Geiger et al., 2020 for details). 

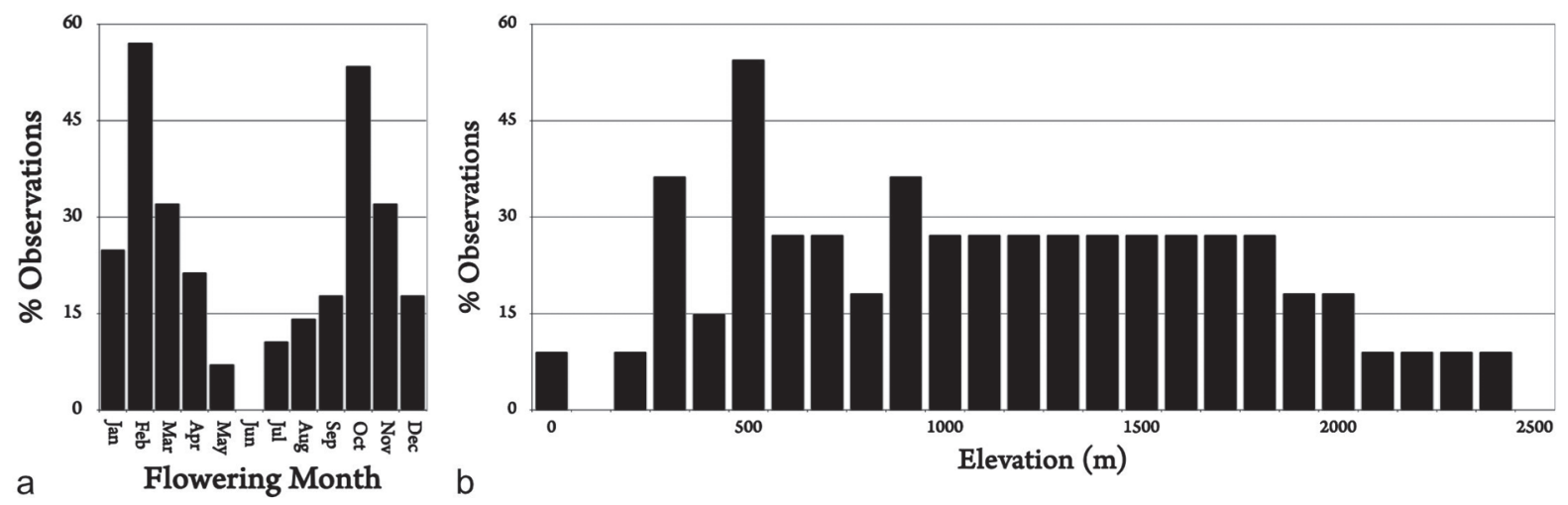

Fig. 5. Summary bar charts of ecological data for Oberonia brachystachys Lindl., compiled from literature under any of its synonyms: a. Phenology data from Ansari and Balakrishnan (1990), Banerji and Pradhan (1984), Blatter and McCann (1931), Bose and Bhatacherjii (1980), Bose et al. (1999), Brühl (1926), Bunpha et al. (2019), Cooke (1907), Cerejo-Shivkar and Shinde (2015), Lucksom (2007), Jalal (2018), Jayaweera (1981), King and Pantling (1898), Nayar et al. (2006), Pradhan (1979), Rao (2000), Raskoti (2009), Santapau (1953, 1967), Santapau and Kapadia (1960), Srivastava (1996), herbarium records, Geiger (pers. obs. in cult.); b. Elevation data from Ansari and Balakrishnan (1990), Bose and Bhattacherjii (1980), Bose et al. (1999), Brühl (1926), Bunpha et al. (2019), De Vlas (2019), Jalal (2018), Jayaweera (1981), King \& Pantling (1898), Lucksom (2007), Mitra (1958), Rajbhandari (2015), Raskoti (2009), Kumar and Manilal (1994), Seidenfaden (1978), Seidenfaden and Smitinand (1959), Srivastava (1996); (graphics by D.L. Geiger).

Oberonia recurva (Fig. 1c) is a synonym of $O$. brachystachys. Both species were introduced by Lindley $(1838,1839)$. Oberonia recurva was described with erose petals (petalis obovatis subdentatis), and a four-lobed lip (labello subrotundo quadrilobo denticulato mucrone interjecto). It was only compared to $O$. wightiana Lindl., with a much larger flower, linear almost entire petals, and with lateral lobes folded over the midline of the flower. It is a typical case where a new species is justified by comparison to a very dissimilar species, as opposed to the most similar ones. The lectotype at $\mathrm{K}$ agrees with the protologue.

While several names have been considered synonyms of $O$. recurva (O. setifera, O. gardneriana, O. parvula, O. croftiana, O. lingmalensis, O. myriantha var. parvula: Jayaweera, 1981; Ansari \& Balakrishnan, 1990; WCSP, 2020), those have not been discussed and justified and are treated here in more detail.

Oberonia setifera Lindl. (Fig. 1g-j; not to be confused with O. setigera Ames from the Philippines) was described with awn-shaped petals (petalia setaceis), and a four-lobed, denticulated lip, and its small vegetative size was noted. The flowers were referred to as being perhaps the smallest in the genus. The lectotype at $\mathrm{K}$ agrees with $\mathrm{O}$. brachystachys. The description of the petals is odd and may be the result of folded over petals.

The drawings on the type sheet of O. setifera by three different authors are illuminating, as it demonstrates the range of interpretations based on the same specimen. Lindley's drawing (Fig. 1g) has rather narrow petals as noted in the protologue and the four lobes of the lip are rather different from the other drawings, but show an erose margin of the lip. The drawings by Hooker (Fig. 1h) and A.S. [? handwriting difficult to read] (Fig. 1i) show the erose and wider petals, and a more typical fourlobed lip. The drawings by Hooker do not show the erose margin of the lip, while that of A.S. illustrates it very clearly. Either those differences are due to artistic license or due to minute differences of flowers from the same plant. Regardless, it shows that those difference are meaningless at the species level and are either variability or artistic license.

Oberonia demissa (Fig. 1d-f) is a synonym of $O$. brachystachys. The small plant with small flowers has unjointed leaves and strongly erose petals. The lip was described by Lindley (1859) as trifid with ovate acute middle lobe [= epichile]. That condition is shown in a drawing (Fig. 1d: presumably by 
Lindley) on the lectotype at K. A second drawing of the flower by J.D. Hooker (Fig. 1e), who collected the plant, shows the more typical fourlobed lip of O. brachystachys. The lobes are shown not as large and distinct as is typical, which could either be an inaccuracy of the drawing or a limitation of the preservation. The state of the specimen did not permit to clearly see the condition of the epichile. The combination of plant size, unjointed leaves, and deeply erose petals is consistent with the identification of this plant as $O$. brachystachys. The drawings of the flowers of $O$. brachystachys (Fig. 1a) and O. demissa by Hooker (Fig. 1e) are indistinguishable.

The exquisite drawing under O. demissa by King and Pantling (1898: pl. 10) shows a flower with lateral lobes of the lip drawn downwards, a distinct constriction of the mesochile, and very small epichile lobes. It appears intermediate between $O$. brachystachys with sub-quadratic lateral lobes and distinct constriction of the mesochile, and the $O$. parvula-morph (see below) with drawn down epichile lobes but little constriction of the mesochile. It is not clear which plant formed the basis of this drawing and, hence, the accuracy of the drawing could not be verified.

Oberonia gardneriana is a synonym of $O$. brachystachys. It was described with a bract more or less as long as the pedicelled ovary, oblong, blunt and denticulate petals (petalis oblongis, obtusis, denticulatis), and a red lip. The lip was not further described and no size indications were provided. It was compared only to O. wightiana (see above for differentiation). While the description is far from complete, that combination of characters is most compatible with $O$. brachystachys amongst the species known from Sri Lanka (Jayaweera, 1981; Fernando et al., 2003; de Vlas, 2019). Members of the section Scyllae (O. bicornis Lindl. [= O. tenuis Lindl.: Geiger, 2019], O. claviloba Jayaw., O. dolabrata Jayaw., O. fornicata Jayaw., O. meegaskumburae Priyad., Wijew. \& Kumar, O. scyllae Lindl., O. walliesilvae Jayaw., O. weragamaensis Jayaw.) have pubescent edges of the petals. This section of Oberonia is in need of critical assessment, which is, however, beyond the scope of this contribution. Oberonia forcipata Lind., O. truncata Lindl., O. wightiana, and O. zeylanica Hook.f. have linear lanceolate petals, O. longibracteata Lindl. has bracts that are much longer than the pedicelled ovary, O. quadrilatera Jayaw. has sessile flowers, and the petals of $O$. thwaitesii Hook.f. are very similar to the ovate triangular sepals. Accordingly, with the available data and historical precedents, it is most likely that $O$. gardneriana is conspecific with $O$. brachystachys. Jayaweera (1981), who had seen the type, listed O. gardneriana under O. recurva, itself a synonym of $O$. brachystachys.

The gathering of the type of O. gardneriana is ambiguous. Thwaites (1861) gave Gardner, in italics but no number, suggesting a gathering. He also gave the number C.P. 593, in roman font, a letter-number combination frequently seen with Thwaites material. As the only specimen at PDA could not be examined and PDA did not respond to inquiries, this matter remains to be fully resolved.

The typification of O. parvula presents some challenges. King and Pantling (1896) neither designated a particular type gathering, nor did they illustrate the species in the protologue itself. The likely original material (Pantling 203) from Teesta valley, $1500 \mathrm{ft}$, is not precisely from the type locality Guru-bathan, $1500 \mathrm{ft}$., specified in the protologue, which is located in the northern most Teesta valley. Despite this minor mismatch, Pantling 203 is clearly original material (See Art. 9.4, Turland et al., 2018). Ansari and Balakrishnan (1990) inadvertently designated the CAL specimen as the lectotype (See Art. 9.3, Turland et al., 2018).

The illustrations of the species in King and Pantling (1898: pl. 6B) with a drawing by R. Pantling, are excellent, certainly represent the original species concept, and clearly identify the species. Although some published drawings are highly inaccurate to misleading (e.g., O. carpina Gilli: see Geiger, 2019), Pantling 203 (K000387743) matches the illustration by King and Pantling (1898) very well with the 
pointed lateral lobes and the acuminate falcate epichile lobes.

Oberonia parvula (Fig. 2a-d) was described in the protologue from Bhutan [today India, West Bengal], Guru-bathan [= Gorubathan, N-most end of Tista river], $1500 \mathrm{ft}$, and no gathering was specified. The lectotype was designated based on likely original material from Teesta valley. The species is typically considered a synonym of $O$. recurva (Ansari \& Balakrishnan, 1990; Rajbhandari, 2015; WCSP, 2020), but has been recognized as a distinct species by a number of authors (Brühl, 1926; Mitra, 1958; Bose \& Bhattacherjii, 1980; Naithani, 1990; Sakkar, 1995a,b; Bose et al., 1999; Lucksom, 2007; Raskoti, 2009). The distinguishing characters between the O. parvula-morph and O. brachystachys include: petals only with irregular outline in $O$. parvula, distinctly to strongly erose in $O$. brachystachys; lateral lobes of lip with downwards expanding tips and entire margin in O. parvula, quadratic with erose lateral margin in $O$. brachystachys; mesochile barely constricted in $O$. parvula, strongly constricted in O. brachystachys; epichile lobes straight or curved towards midline with entire margin in O. parvula, expanding laterally away from midline with strongly erose margin in O. brachystachys. The very limited number of samples, the intermediate forms known e.g. as $O$. croftiana (see below), the illustration under $O$. demissa by King and Pantling (1898: pl. 10: see above), and the known extensive intraspecific variability in Oberonia species demonstrated by molecular phylogenetic studies (Li et al., 2016; Geiger et al., 2020), however, suggests that $O$. parvula is a mere morph of O. brachystachys.

The O. parvula-morph shares some floral characteristics with $O$. acaulis, such as the drawnout tip of the lateral lobe. Those similarity may have been the reason to consider it a variety of $O$. myriantha Lindl., a synonym of $O$. acaulis Griff.: $O$. myriantha var. parvula (King \& Pantl.) Tang \& Wang. Tang and Wang (1951) based their assessment purely on vegetative characters, but even the jointed leaves of $O$. acaulis do not agree with the unjointed leaves of $O$. brachystachys. Additionally, O. acaulis has much longer leaves even in small plants, the bract is serrated (not entire or slightly erose), the mesochile of the lip shows a distinct constriction, and the apical lobes diverge from the mid-line. The coloration of the flower typically shows a darker spot in the disc area not known from O. brachystachys. Accordingly, O. parvula is here synonymized under O. brachystachys, while $O$. acaulis is a distinct species. The same conclusion was reached by Seidenfaden (1968).

The specific epithets myriantha and acaulis were recently confused by Bunpha et al. (2019), along with several other misinterpretations about the taxonomy of Oberonia species. It is beyond the scope of this contribution to correct those problems.

The type material of $O$. croftiana presents some challenges. The protologue gave Sikkim-Bhutan frontier, on the banks of the Jaldakha river, $900 \mathrm{ft}$. as the type locality for Pantling 254. Pantling gatherings were not necessarily collected at a particular time, and may not have been from the exact same place, hence, do not constitute a gathering in the conventional sense: one species from a particular locality at a particular time (A. Schuiteman, pers. comm.). In the case of O. croftiana, Pantling 254 in W (W5951) and L (L0061772) were collected at Dikling at $2000 \mathrm{ft}$., some $20 \mathrm{~km} \mathrm{~W}$ of the border to Bhutan and approximately $50 \mathrm{~km}$ NW of the Jaldakha river, in February, 1897. Pantling 254 first-step lectotypes CAL0000000048 and CAL0000000049, and isolectotypes AMES 72805/HUH00101950, K000387742 and P00404879 were collected in Tropical Valley in October 1893. While the localities of all those specimens do not precisely match the indication in the protologue, they are considered here part of the lectotype series; it certainly is original material in the sense of Turland et al. (2018). CAL0000000048 was annotated as "Type" by Ansari in 1985. However, no specific sheet of the two at CAL was explicitly referred to in any publications, the mention of CAL as type repository only qualifies as a first-step lectotypification (See 
Art. 9.17, Ex. 14, Turland et al., 2018). We here explicitly designate CAL0000000048 as lectotype by second-step lectotypification.

Oberonia croftiana (Fig. 2e-h) is a synonym of $O$. brachystachys. The species has been given as a synonym of O. recurva in the literature (Ansari \& Balakrishnan, 1990; WCSP, 2020). It has been considered a correct name by some (Brühl, 1926; Mitra, 1958; Bose \& Bhattacherjii, 1980; Naithani, 1990; Sakkar, 1995a; Bose et al., 1999; Lucksom, 2007). It is notable, that the authors who consider both O. parvula and O. croftiana distinct are almost identical. We have not found any publication that considers $O$. parvula with synonym of $O$. croftiana as distinct from O. brachystachys/recurva. The shared characters between O. croftiana and O. brachystachys include the lateral lobes of the lip with erose margin and distally extended tip, the constriction of the mesochile, and the epichile lobes with erose margin. Lucksom (2007: fig. 163) illustrated a drawing under the name O. parvula that shows an intermediate condition between the illustrations of O. parvula and O. croftiana, which lends support to the synonymy of the two taxa. Lucksom's (2007: fig. 162) illustration of O. croftiana shows a specimen with even more pronounced falcate epichile lobes. A drawing on the isolectotype (P00404879, Fig. $2 \mathrm{~g}$ ) shows rather different interpretation of the flower: petals entire and not erose, lateral lobes of the lip, not downward sloping, and epichile lobes short and square, not elongated sub-falcate. It is a further example of how the same plant may be interpreted differently. A drawing and annotation of the flower on isolectotype (CAL0000000049) by Shakya in 1997 shows the lateral lobes expanding laterally without downturned tips and noted the epichile lobes are entire. Those differences compared to the drawings on the other isolectotypes and the drawing by King and Pantling (1898: pl. 6A) are a clear indication of intraspecific variability. The alternate explanation that the type gathering from Tropical Valley at CAL and P is composed of multiple, barely distinguishable species is too far-fetched.
Blatter and McCann (1931) compared O. lingmalensis only to O. verticillata from which it was distinguished by the flatter scape, the slightly erose linear bracts of variable length, long pedicelled ovary, and erose petals. The species has been considered a variety of $O$. recurva by Santapau and Kapadia (1960, 1966), Sharma et al. (1984) and Naithani (1990). The characters given by Blatter and McCann (1931) are congruent with $O$. brachystachys, specifically the vegetative description (no indication on jointed or unjointed leaves), the size of the flowers $(2 \mathrm{~mm})$, the shape of the bract, the erose petals, and the lip with erose lateral and epichile lobes. The species has never been illustrated. The holotype could not be examined and the repositories of the paratypes are unknown.

For O. brachyphylla, Blatter and McCann (1931) did not designate any type material. Their illustration was prepared from a live specimen, and the fate of that plant is unknown. The neotype designation by Santapau and Kapadia (1960) is in violation of Art. 9.19(a) of Shenzhen Code (Turland et al., 2018), because the illustration in the protologue constitutes original material (Art. 9.4b). Any original material must be considered for lectotypification before a neotype can be designated. Accordingly, the neotype designation by Santapau and Kapadia (1960) is here superseded by the lectotypification of O. brachyphylla through the illustration of the protologue (Blatter \& McCann, 1931: pl. 2).

Oberonia brachyphylla (Fig. 1k,1) and O. brachystachys share the small vegetative size, the lack of jointed leaves, the small flowers $(1.5 \mathrm{~mm})$, the oval petals with erose margins, and the four-lobed lip with erose margins of the lateral lobes, entire constricted mesochile, and erose edges of the epichile lobes. The plant illustrated by Blatter and McCann (1931) is somewhat smaller than the types of the other names. Those size and slight shape differences of the leaves fall well within the known variability in other species, particularly O. rufilabris Lindl. (Geiger, pers. obs.). Blatter and McCann (1931) compared their species only to O. recurva and neglected O. brachystachys. They distinguished $O$. 
brachyphylla from O. recurva by the leaf shape (demonstrably highly variable), longer inflorescence (demonstrably highly variable in many species: Geiger, 2019), oblong sub-acute petals (no difference), lip much longer than the sepals (no difference), mid lobe square, bifid and incurved (no difference). Accordingly, the differentiation was based on lack of knowledge on intraspecific variability and outright errors, hence, $O$. brachyphylla is treated here as the synonym of $O$. brachystachys.

The alleged occurrence of O. brachystachys in China (Seidenfaden, 1968) is questionable (Chen et al., 2009: as O. recurva). Given the past confusion of $O$. brachystachys and $O$. subligaculifera and their synonyms, Seidenfaden's (1968) indication may be based on $O$. subligaculifera, which would match distributional patterns of the two species better.

Mitra (1958) listed Malaxis cordifolia Rchb.f. as the correct name for $O$. demissa. There are two $M$. cordifolia listed in WCSP (2020): Sm. in A.Rees, 1812, and the nom. illeg. by (Rolfe) Ames \& C. Schweinf. in O. Ames, 1920. The former is considered a synonym of Liparis petiolata (D.Don) P.F.Hunt \& Summerh. It is not clear what name Mitra (1958) was referring to. In any case, any potential Reichenbach name cannot threaten $O$. brachystachys, as Reichenbach's orchid species names are all from after 1845 and placement in Oberonia would be after that.

AMES 72799/HUH 00101944 is listed in AMES on-line catalogue as a possible isotype of $O$. brachystachys. However, given the specific collector and gathering numbers cited by Lindley (1838), which are not present on the AMES sheet, that specimen has no type standing at all.

The variability of $O$. brachystachys seems extensive, some may even suspect excess lumping of taxa. However, based on available material and information, it is impossible to form distinct groupings that would segregate the plants consistently with more than one character. For instance, the degree of serration of the petals is not correlated with the degree of serration of the lip, and neither is correlated with shape of the epichile lobes on the lip. The variability of the sac from a small depression (Figs. 3k,n, 4b,e,f) to distinct cavity (Fig. 3c,d) is surprising. All other flower attributes of Figure 4 with minute sac and the live plant of Figure $3 \mathrm{c}, \mathrm{d}$ with distinct sac are identical. Ansari and Balakrishnan (1990: fig. 32g, $35 \mathrm{~g}, 36 \mathrm{~g}-\mathrm{i}$ ) seem to have noticed different extents of the sac formation as indicated by the shading in the central upper portion of the lip. The combination of absence of other confirming characters and evidence of variability by Ansari and Balakrishnan (1990) suggest as the simplest explanation that the sac condition is variable in O. brachystachys. To demonstrate distinct groupings, much more material would need to be collected, and the morphological data would ideally be supported with molecular techniques. The latter approach has demonstrated extensive intraspecific variability in Oberonia species (Geiger et al., 2020).

Oberonia subligaculifera J.J.Sm., Bull. Jard. Bot. Buitenzorg, sér. 2, 9: 35. 1913. Holotype: INDONESIA, Java, Jawa Barat, near Tirtasari, $1500 \mathrm{~m}$, J.J. Smith \& Rant 201 (repository unknown).

Oberonia bambusicola Kerr, Bull. Misc. Inform. Kew 1927: 213. 1927. Syntype: THAILAND, Chon Buri, Sriracha [= Si Racha], Nang Khaw, 50 m, Kerr 383 (K [K000596096]!).

Oberonia evrardii Gagnep., Bull. Soc. Bot. France 76: 326. 1929. Lectotype: (inadvertent designation by Seidenfaden, 1968: 48 by reference to "P!, type"): VIETNAM, Lam ĐÑng, Dalat, chalet Rimaud, 28.10.1920, Evrard 300 (P [P00404954]!).

Oberonia kanburiensis Seidenf., Bot. Tidsskr. 68: 47. 1973. Type: THAILAND, Kanchanaburi, West of Siswat, Hauy Ban Kao, Beusekom et al. 3657 (holo C (C2103) n.v., iso L [L0061749]!).

Oberonia arunachalensis A.N.Rao, Rheedea 7: 130. 1997. Type: INDIA, Arunachal Pradesh, Lohit district, Kamlang Reserve forest on way to 
Chamba-glowlake area, 500 m, A.N. Rao 28067 (holo OHT n.v.). syn. nov.

Oberonia raoi L.R.Shakya \& R.P.Chaudhary, Rheedea 10: 57. 2000 ["raoii"]. Type: INDIA, Meghalaya, Khasia hills, Nongpoh, 4000 ft. (1219 $\mathrm{m}$ ), August 1897, Pantling s.n. (holo CAL [CAL0000024756]!). Erroneous citation of type gathering in protologue, see below. syn. nov.

Oberonia kamlangensis A.N.Rao, J. Econ. Taxon. Bot. 24: 267. 2000. Type: INDIA, Arunachal Pradesh, Lohit district, Kamlang sanctuary, $150 \mathrm{~m}$, A.N. Rao 28283A (holo OHT n.v.); ibid, A.N. Rao 28283-B (para CAL n.v.); ibid. A.N. Rao 28283-C (para OHT n.v.). syn. nov.

Figs. $6 \& 7$

Epiphytic herbs, usually 4-6 leaves, jointed, forming stemless fan. Leaves narrow elongated acuminate, acute, typically slightly falcate towards or away from growth axis, typically $2-8 \mathrm{~cm}$ long, $0.3-0.5 \mathrm{~cm}$ wide. Roots thin, fibrous, unbranched. Inflorescence typically $5-10 \mathrm{~cm}$ long, typically 2$3 \times$ as long as leaves. Scape short, rachis longitudinally grooved, flowers variable arranged from distinct whorls, to in spiral, or scattered. Flowers 2.0-2.5 × 2.2-3.0 mm, average 2.5 × 2.5 $\mathrm{mm}$, green, yellow-orange, orange. Bracts, elongated acuminate, acute, erose, about as long as flower. Pedicelled ovary round, 2.0-2.5 mm long. Orientation of all tepals somewhat forward or somewhat recurved. Sepals broad oval acute. Petals oblong obtuse, erose to dentate or laciniate. Lip four-lobed, lateral lobes square or trapezoidal, margin erose to dentate; mesochile more or less constricted, entire; epichile lobes truncated, rounded or sub-quadrate, margins dentate or erose, disc indistinct, sac unknown.

Flowering: Flowering throughout year with peaks in February and October (Fig. 7a). The gap in JuneJuly is considered a data artifact.

Habitat: Erect or pendulous epiphyte, evergreen to deciduous, broad-leaf, mixed and conifer forest, on branches of tree and shrubs, on bamboo, in coffee plantation, 0-2400 m, predominantly below 900 m (Fig. 7a).
Distribution: India, Malaysia, Myanmar, Thailand, Vietnam, China, Indonesia, Philippines (Luzon) (Kerr, 1927; Santapau \& Kapadia, 1960; Backer \& Bakhuizen van der Brink, 1968; Seidenfaden, 1968, 1978; Saldanha in Saldanha \& Nicolson, 1976; Pradhan, 1979; Abraham \& Vatsala, 1981; Manilal, 1988; Comber, 1990; Naithani, 1990; Sakkar, 1995a; Turner, 1995; Hop, 1998; Bose et al., 1999; Averyanov \& Averyanova, 2003; Kumar \& Manilal, 2004; Rao, 2010; Averyanov, 2013; Bunpha et al., 2013, 2019; Jin et al., 2019; herbarium records).

Specimens examined: INDONESIA, Java, Bandong, Zollinger 897 (P[P00428170: left]). Sumatra, Gunung Leuser Nature Reserve, Atjeh, Ketambe valley of Lau Alas, near tributary of Lau Ketambe, de Wilde \& de Wilde-Duyfjes 12267 (K). MALAYSIA, Sarawak, Marudidistrict between Bario and $\mathrm{Pa}$ Umor, Beaman 11256 (K). MYANMAR, King Lung, MacGregor 822 (E [E00616243]). PHILIPPINES, Luzon, Cordillera Administrative Region, Bontoc. Vanoverbergh 3828 (F [F452930], MO [MO799960]). THAILAND, Mae Hong Son, Khun Yuam, Larsen \& Larsen 34115 (K). VIETNAM, Ha Lang, Thanh Nhat, $42 \mathrm{~km}$ E of Cao Bang, Averyanov CLB 732 (MO [MO04970868]). Noh Quan, Cuc Phuong National Park, CP146; Cuong et al. 775 (MO [MO5336640]).

Notes: The repository of the holotype of $O$. subligaculifera J.J.Sm. is unknown. The specimen is a holotype as the protologue specified that it was based on a single specimen. The species (Fig. 6a) and its previous recognized synonyms (Geiger, 2019) O. evrardii (Fig. 6d,e) and O. kanburiensis (Fig. $6 \mathrm{f}, \mathrm{g}$ ) is characterized by the elongate acuminate jointed leaves, the larger flowers $(1.8-2.5 \times 2.2-$ $3.0 \mathrm{~mm}$ ), petals with strongly erose to incised margins, the four lobed lip with strongly erose to incised lateral lobes, a constriction of the entire mesochile, and a bifid epichile with erose to incised tips. Although the flowers are very similar to those of O. brachystachys, the jointed leaves of $O$. 

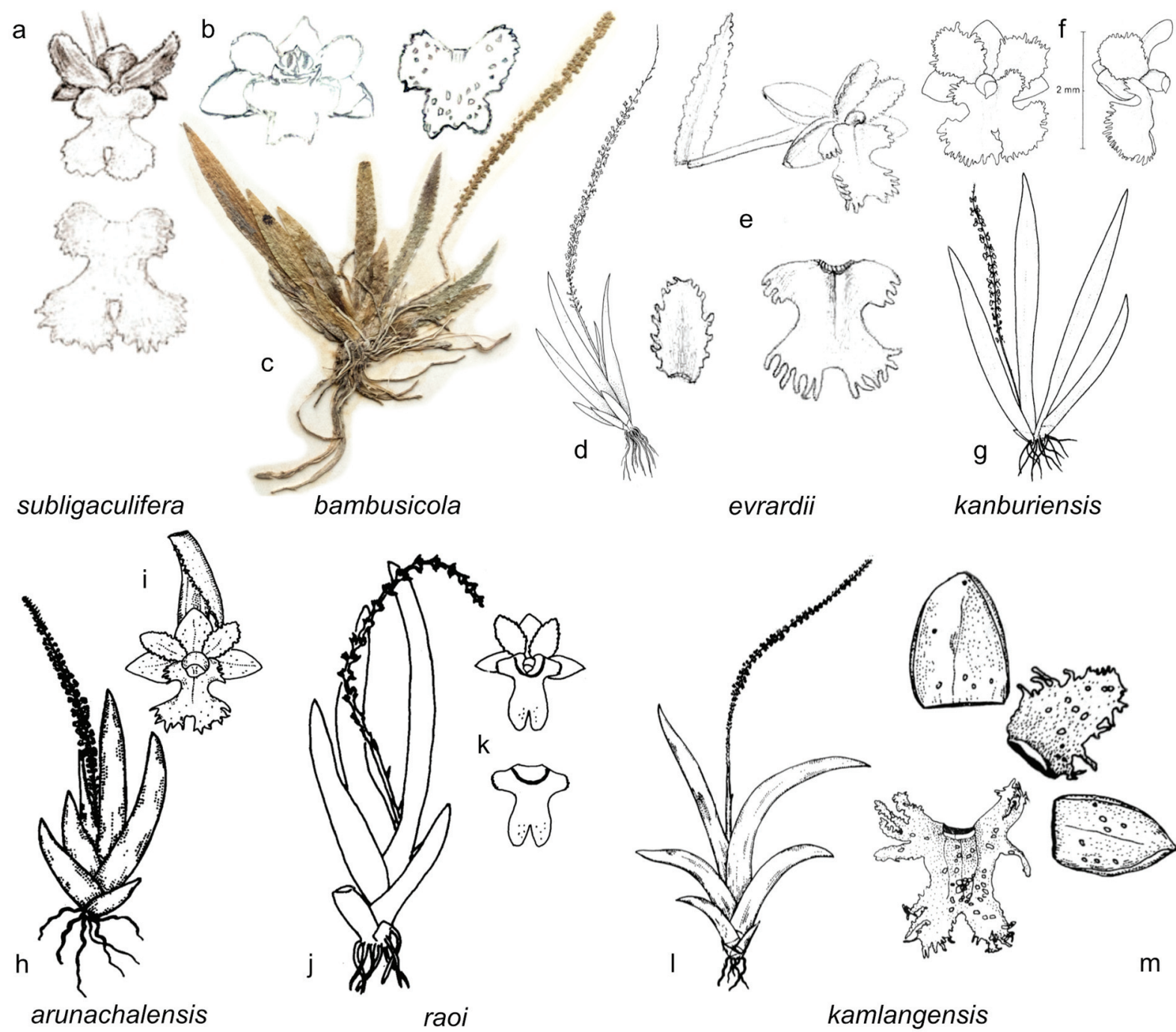

Fig. 6. Drawings and photographic image of Oberonia subligaculifera J.J.Sm. and its synonyms: a. O. subligaculifera illustration by J.J. Smith from Schuiteman and de Vogel (2006), entire flower and isolated lip; b,c. 0. bambusicola Kerr 383 (syntype K [K000596096]); b. Drawing of flower and lip on note affixed to type sheet; c. Habit; d,e. O. evrardii Gangnep.; d. Drawing of lectotype Evrard 300 (P [P00404954]) by Seidenfaden (1968: fig. 27); e. Drawing on lectotype sheet of entire flower, isolated lip, and isolated petal; f,g. O. kanburiensis Seidenf. drawing of type from Seidenfaden (1978: fig. 9); f. Flower; g. Habit; h,i. O. arunachalensis A.N. Rao drawing from Rao (1997: fig. 1); h. Habit; i. Flower; j,k. O. raoi L.R. Shakya and R.P. Chaudhary drawing from Shakya and Chaudhary (2000: fig. 1); j. Habit; k. Flower; I,m. O. kamlangensis A.N. Rao drawings from Rao (2000: pl. 1); I. Habit; m. Flower parts digitally rearranged to natural positions; (a, d, f-m from cited publications under fair use provision of copyright law; photos b,c,e by D.L. Geiger).

subligaculifera (unjointed in O. brachystachys) in combination with the typically larger flowers indicate that they are distinct species. While intraspecific variability is extensive in Oberonia, the jointed vs. unjointed leaves have never been suggested as variable within species. On the contrary, that character has been used to separate the genus Oberonia into two subgenera (Schlechter, 1911): Oberonia s.s. [= Apothemnophyllum Schtr.] with jointed leaves, and Menophyllum Schltr. with unjointed leaves.
Bunpha et al. (2019) considered O. evrardii distinct from O. subligaculifera based on differences in the depression of the lip and the shape of the rostellum. Neither of those characters were illustrated, and the sample size for those two species were four and five, respectively. The difference is at best subtle, with significant intraspecific variability demonstrated previously (Geiger, 2019). Those characters are considered insignificant. The shape of the rostellum is likely 


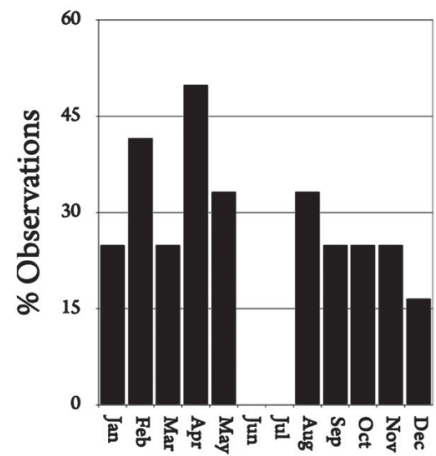

a

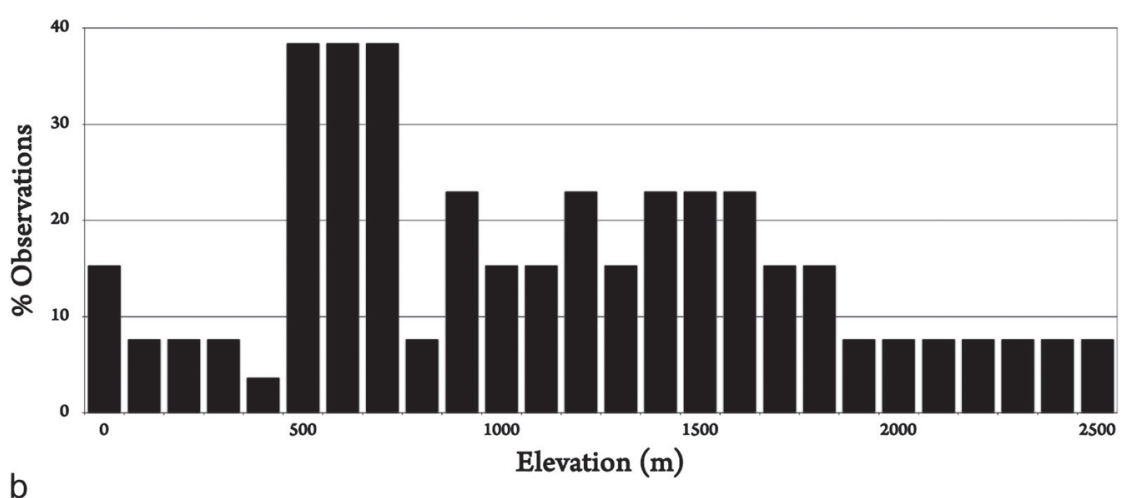

Fig. 7. Summary bar charts of ecological data for Oberonia subligaculifera J.J.Sm., compiled from any of its synonyms: a. Phenology data from Smith (1913), Santapau and Kapadia (1960), Saldanha and Nicolson (1976), Abraham and Vatsala (1981), Manilal (1988), Ansari \& Balakrishnan (1990), Nayar et al. (2006), Bunpha et al. (2013, 2019 ), Jin et al. (2019), herbarium records; b. Elevation data from Smith (1913), Kerr (1927), Ansari and Balakrishnan (1990), Seidenfaden (1992), Rao (1997), Averyanov et al. (2000), Averyanov and Averyanova (2003), Averyanov (2013), Bunpha et al. (2013, 2019), Jin et al. (2019), herbarium records; (graphics by D.L. Geiger).

affected by ontogeny and state of maturation, hence, is meaningless.

Oberonia bambusicola Kerr (Fig. 6b,c) had been considered a synonym of $\mathrm{O}$. brachystachys (Seidenfaden, 1968; WCSP, 2020), but is here placed in synonymy with $O$. subligaculifera. The shared characters between O. bambusicola and $O$. subligaculifera include the jointed leaves (visible in $\mathrm{K}$ syntype), the size of the flowers $(>3 \mathrm{~mm})$, the greenish flower color (in fluid preserved specimen), the erose petals, and all aspects of the lip. It differs from O. brachystachys by the jointed vs. unjointed leaves, the larger flowers (>3 mm vs. $\sim 1.5 \mathrm{~mm}$ ), and the flower color (green vs. red). While the size of the flower was not given by Kerr (1927), it can be inferred by adding his measurements of the lip ( 2.2 $\mathrm{mm}$ long) and the sepal (1.5 mm long).

Kerr (1927) compared his species only to O. recurva and noted the proportionally shorter lip and the less erose petals. The annotations by Kerr preserved on the type sheet identify his specimen as cf. $O$. brachystachys, a further indication to the synonymy of O. brachystachys and O. recurva discussed above. He did not mention O. subligaculifera.

Oberonia arunachalensis (Fig. 6h,i) is a synonym of O. subligaculifera. It shares the fan-shaped habit, the jointed leaves (according to protologue, not evident in figure), the oval and erose petals, and the lip shape with serrated lateral lobes and epichile lobes with $O$. subligaculifera. The two names refer to the same species. Rao (1997) compared his O. arunachalensis only with O. kanburiensis, and distinguished the two by the longer leaves and inflorescence (both extensively variable within species), green flowers (no difference), elliptical-elongate petals (no difference) and dentate lobes of the lip (no difference). Accordingly, the differentiation was based on lack of knowledge of intraspecific variability and outright mistakes.

The flowers appear to be rather small $(c .1 .7 \times 1.4$ $\mathrm{mm}$ ) based on the scale bar associated with the flower. Errors in scale bars and drawings are abundant in micro-floral orchids (Geiger, 2019). According to the scale bar of the entire flower (Rao, 1997: fig. 1d) the bract is $1.3 \mathrm{~mm}$ long, while the isolated bract shown in Rao (1997: fig. 1e) is 1.5 $\mathrm{mm}$ long based on its scale bar. Whether this should illustrate variability of floral parts on the same inflorescence or whether those are scale bar errors is unclear. Even with a $15 \%$ variance in measurement accuracy, the flowers of $O$. arunachalensis would be rather small for $O$. subligaculifera and more compatible with $O$. brachystachys. Intraspecific variability of floral size by up to $50 \%$ have been documented in other species (O. complanata: Geiger, 2019; O. equitans: Geiger et al., 2020); O. arunachalensis falls within 
that documented range of intraspecific variability with respect to O. subligaculifera. The jointed leaves according to protologue, not shown in Rao (1997: figs. 1c; fig. $6 \mathrm{~h}$ ), in addition to the more eastern type locality is indicative of a synonymy with $O$. subligaculifera.

The protologue of $O$. raoi misspelled the specific epithet as raoii, an error already noted by Badyopdhyay et al. (2016). The protologue further mistook an old herbarium ledger number [449798] as the gathering number of the type; the correct citation of the gathering is Pantling s.n.

Oberonia raoi (Fig. 6j,k) is a synonym of $O$. subligaculifera. The common characters include the habit with jointed leaves, the erose margins of the ovate petals, the overall shape of the lip, and the erose margin of the square lateral lobes at right angle to the axis of the lip. The only character not matching are the margins of the apical lobes of the lip, which are distinctly erose in O. brachystachys while appearing entire in the drawing of O. raoi. However, the quality of the drawing is not particularly good and one may wonder whether artistic license missed those small details. Given the large number of matching details including the jointed leaves, O. raoi is here synonymized under O. subligaculifera. Oberonia raoi was only compared to O. myriantha (= O. acaulis) and not to $O$. subligaculifera.

Oberonia kamlangensis (Fig. 61,m) is a synonym of O. subligaculifera. It was compared to O. mucronata (D.Don) Ormerod \& Seidenf. in G.Seidenf., but not to O. subligaculifera or to $O$. arunachalensis described by the same author three years earlier (Rao, 2000). It is another case where a new species is justified by comparison to a very distant and different species while the more similar species were not considered. Oberonia kamlangensis is indistinguishable from $O$. arunachalensis, itself a synonym of O. subligaculifera. The jointed leaves, the strongly erose petals, and the lip with strongly laciniate lateral lobes and the equally deeply incised epichile lobes (Fig. 6h,l,m) are shared by the two nominal species.
The flower color was given as pale yellow-green by Smith (1913), but the description was based on ethanol-preserved material. Ethanol bleaches the flower color (Geiger, pers. obs.) with orange flowers turn yellow green. Green flowers have been reported by Rao (1997: as O. arunachalensis). Variability in flower color from green to orange is well-known in O. mucronata (Geiger, 2019).

\section{Discussion}

The untangling of the two species discussed here leads to a consistent overall pattern. The names are distinguished by size of the flowers $(1.0-1.75 \mathrm{~mm}$ in O. brachystachys, 1.8-3.0 mm in O. subligaculifera), the un-jointed leaves in O. brachystachys, but jointed ones in O. subligaculifera. Oberonia brachystachys is distributed from western and southern India, including Sri Lanka to Myanmar, while O. subligaculifera is found from easternmost India to Java and the Philippines.

The synonymy of O. parvula/croftiana under $O$. brachystachys may appear too sweeping. The limited sample size, the documented intermediate forms, and the known extensive intraspecific variability demonstrated with molecular techniques (Li et al., 2016; Geiger et al., 2020) support our conclusion as the best explanation of all data. It would be worth-while to investigate the matter further with combined floral (z-stack light microscopy, SEM) and molecular data of the same specimens exhibiting a range of morphologies. It might be the case that the parvula-morph of O. brachystachys is a species in statu nascendi, i.e., that those specimens represent lineages that are in the process of diverging. However, the divergence does not seem to be complete, and does not need to be recognized taxonomically at this point in time.

As shown in other cases, the microfloral Oberonia were over-described due to lack of knowledge of intraspecific variability, focussing on minute differences of individual plants rather than applying population thinking in systematics, citing characters as differences that are in fact identical, and comparing new names to highly 
dissimilar species rather than the more similar ones. The last factor may also be caused by lack of knowledge of obscure plant groups. Ideally, in order to describe a new species in a genus, every name ever described in this genus has to be understood by the proposer of the new name. That entails a revision of the entire genus, either already published, or carried out by the describer. Obscure groups by their very nature have not been revised. Accordingly, describing new species in obscure plant group has a high potential of introducing synonyms (Geiger, 2021).

Geiger et al. (2020) additionally discussed the higher academic recognition for introducing new names as opposed to recognizing synonyms, and the lack of a malus for burdening systematics with excess names. We here discuss additional examples showing multiple incongruent drawings from the same specimen, while providing superior photographic images and scanning electron micrographs.

Focus on political geographic units is a further contributing factor. A case in point is the Indian synonyms of O. subligaculifera described from Indonesia. The dispersal potential of Oberonia spp. is extensive due to their minute seeds (Bartholott et al., 2014; Geiger, 2014, 2020, unpubl. data; Geiger et al., 2020), and has been confirmed by molecular data (Geiger et al., 2020). Accordingly, new distributional records of already described species are too often mistaken as new species. Postulated microendemic Oberonia species (Averyanov, 2013; Averyanov et al., 2015, 2019) are most likely synonyms of already described species (Geiger, 2020, 2021, unpubl. data).

\section{Acknowledgements}

The authors are grateful to Ministry of Environment, Forest \& Climate Change for funding the Flora of India Project; Dr. A.A. Mao, Director, Botanical Survey of India, Kolkata, Dr. M.U. Sharief, Head of Office, Botanical Survey of India, Southern Regional Centre, Coimbatore for the providing the facilities and support to carry out the work; Dr. K. Karthigeyan (CNH) for consulting herbarium and to Kerala Forest Department for granting the field permission. DLG was accommodated during various collection visits at the following herbaria: Jacek Wajer (BM), Hanna Atkins and Suzanne Cubey (E), Christine Niezgoda (F), André Schuiteman (K), Wayne Gerbet (MEL), James Solomon and Donna Herrera (MO), Marc Pignal (P), Rusty Russell (US), Ernst Vitek (W), Walter Till (WU). The reviewers and editor helped to improve the manuscript.

\section{Literature Cited}

ABRAHAM A. \& P. VATSALA 1981. Introduction to orchids with illustrations and descriptions of 150 South Indian Orchids. Tropical Botanical Garden and Research Institute, Thiruvanathapuram.

ANNONYMOUS n.d.b. Annual Report, 2015-2016. Botanical Survey of India-Ministry of Environment, Forest \& Climate Change. Botanical Survey of India, Kolkata. [probably published 2016 or 2017].

ANSARI R. \& N.P. BALAKRISHNAN 1990. A revision of the Indian species of Oberonia (Orchidaceae). Orchid Monographs 4: i-iv, 1-82.

AVERYANOV L.V. 2013. The orchids of Vietnam illustrated survey. Turczaninowia 16: 5-163.

AVERYANOV L.V. \& A.L. AVERYANOVA 2000. Rare species of orchids (Orchidaceae) in the flora of Vietnam. Turczaninowia 3: 5-87.

AVERYANOV L.V. \& A.L. AVERYANOVA 2003. Updated checklist of the orchids of Vietnam. Vietnam National University Publishing House, Hanoi.

AVERYANOV L., NGUYEN K.S. \& T. MAISAK 2019. Plant diversity, flora and vegetation of Hin Nam No protected area. Lambert Academic Publishing, Mauritius.

AVERYANOV L.V., NGUYEN T.H., PHAN K.L. \& A.L. AVERYANOVA 2000. Preliminary orchid checklist of Cao Bang Province (Vietnam). Lindleyana 15: 130-164.

AVERYANOV L.V., NGUYEN K.S., NGUYEN T.T., NGUYEN P.T., NONG V.D., NGUYEN V.C. \& C.C. XUAN 2015. New orchids in the flora of Vietnam. Wulfenia 22: 137-188.

BACKER, C.A \& R.C. BAKHUIZEN VAN DEN BRINK JR 1968. Flora of Java (Spermatophytes only). Volume 3. Wolters-Noordhoff, Groningen.

BANDYOPDHYAY S., KRISHNA G. \& P. VENU 2016. Names of new taxa published and types deposited - a 
case study. Annals of Plant Science 5: 1451-1457. https:// doi.org/10.21746/aps.2016.10.001

BANERJI M.L. \& P. PRADHAN 1984. The orchids of Nepal Himalaya. J. Cramer, Vaduz.

BARTHLOTT W, GROSSER-VELDMANN B. \& N. KOROTKOVA 2014. Orchid seed diversity, a scanning electron microscopy survey. Englera 32: 1-245.

BLATTER E. \& Y.M.C. McCANN 1931. Revision of the flora of the Bombay Presidency. The Journal of the Bombay Natural History Society 35: 251-275.

BOSE T.K. \& S.K. BHATTACHARJEE 1980. Orchids of India. Naya Prokash, Calcutta.

BOSE T.K., BHATTACHARJEE S.K., DAS P. \& U.C. BASAK 1999. Orchids of India, Revised Edition. Naya Prokash, India.

BRÜHL P. 1926. A Guide to the Orchids of Sikkim. Thacker, Spink \& Co., Calcutta.

BUNPHA K., PEDERSEN H.Æ. \& K. SRIDITH 2013. Establishing species distributions in large tropical plant genera: insights from twelve new Thai records of Oberonia (Orchidaceae). Blumea 58: 71-76. https:// doi.org/10.3767/000651913X672299

BUNPHA K.O., SRIDITH K. \& H.Æ. PEDERSEN 2019. A taxonomic revision of Oberonia (Orchidaceae: Epidendroideae: Malaxideae) in Thailand. Phytotaxa 420: 102-156. https://doi.org/10.11646/phytotaxa.420.2.2

CERJO-SHIVKAR S. \& R.D. SHINDE 2015. A brief account of Orchidaceae in Sanjay Gandhi National Park, Mumbai, India. Journal of Threatened Taxa 7: 7787-7295. https://doi.org/10.11609/JoTT.o4213.7287-95

CHEN X., ORMEROD P. \& J.J. WOOD 2009. 81. Oberonia Lindley. In: WU Z.Y., RAVEN P.H. \& D.Y. HONG (eds.), Flora of China. Volume 25. Science Press, Beijing. pp. 236-245.

CHOWLU K. \& K.S. RAB 2017. Oberonia jhae: a new species of orchid from Arunachal Pradesh, India. Bangladesh Journal of Plant Taxonomy 24: 49-52. https://doi.org/ 10.3329/bjpt.v24i1.33005

CHOWLU K., DEVI Y.N., RAO A.N., ANGELA N., SHARMA H.B. \& G. AKIMPOU 2015. Oberonia manipurensis sp. nov. (Orchidaceae) from Manipur, India. Nordic Journal of Botany 33: 42-44. https://doi.org/ 10.1111/njb.00591

COMBER J.B. 1990. Orchids of Java. Bentham-Moxon Trust, Royal Botanic Gardens, Kew.

COOKE T. 1907. The Flora of the Presidency of Bombay, Volume III, part IV. Botanical Survey of India, Calcutta. pp. 625-816 [123-326 in 1967 reprint examined].

DE VLAS J. 2019. Illustrated field guide to the flowers of Sri Lanka. Volume 3. Privately published, The Netherlands.
FERNANDO M., WIJESUNDARA S. \& S. FERNANDO 2003. Orchids of Sri Lanka, a conservationists companion. A simplified guide to identification. Volume 1. The protected orchids and selected similar species. IUCN Sri Lanka, Colombo.

GEIGER D.L. 2014. Oberonia, the microscopist's delight. Orchids 83: 558-563.

GEIGER D.L. 2016. Studies in Oberonia 1: Oberonia maxima and its new synonyms. Orchids 85: 390-395.

GEIGER D.L. 2019. Studies on Oberonia 5 (Orchidaceae: Malaxideae). Twenty-four new synonyms, and a corrected spelling. Blumea 64: 123-139. https://doi.org/ 10.3767/blumea.2019.64.02.04

GEIGER D.L. 2020. Studies in Oberonia 8 (Orchidaceae: Malaxideae). Additional 24 new synonyms, a corrected spelling, and other nomenclatural matters. Blumea 65: 188-203. https://doi.org/10.3767/blumea.2020.65.03.02

GEIGER D.L. 2021. Studies in Oberonia 9. Lessons from excess names in Oberonia for Orchidaceae systematics, including a revision of the Oberonia Sect. Scytoxiphium. Lankesteriana 21: 139-156. https://doi.org/10.15517/ lank.v21i2.47245

GEIGER D.L., CRAIN B.J., MCCORMICK M.K. \& D.F. WHIGHAM 2020. Studies in Oberonia 7. Ten new synonyms of Oberonia equitans (G.Forst.) Mutel indicated by morphology and molecular phylogeny. Orchids 89: 656-667.

GOGOI K. \& R. YONZONE 2016. Oberonia rufilabris Lindley (Orchidaceae): a new record for the State of Assam, India. Pleione 10: 199-202.

HOOKER J.D. 1888. Icones Plantarum or figures, with brief descriptive characters and remarks, of new and rare plants. Series 3, Volume 8/18. Dulau \& Co., London.

HOP T. 1998. Phong Lan Viêt Nam (The Orchids of Vietnam). Khoa Hoòc kyP thuaòt, Hanoi.

JALAL J.S. 2018. Orchids of Maharashtra. Botanical Survey of India, Kolkata.

JAYAWEERA D.M.A. 1981. Orchidaceae. In: DASSANAYAKE M.D. (ed.), Revised Handbook of the Flora of Ceylon. Volume 2. Amerind Publishing Co. Pvt. Ltd., New Delhi. pp. 4-386.

JIN X., LI J. \& D. YE (eds.) 2019. Atlas of Native Orchids in China. Henan University of Science and Technology, Henan.

KALIAMOORTHY S. \& T.S. SARAVANAN 2019. Additions to the orchid flora of Peninsular India. Rheedea 29: 319-322. https://dx.doi.org/10.22244/rheedea. 2019.29.4.05

KERR A.F.G. 1927. Contributions to the flora of Siam. Additamentum XXII. Bulletin of Miscellaneous Information 1927: 212-220. 
KING G. \& R. PANTLING 1896. On some new orchids from Sikkim. Journal of the Asiatic Society of Bengal 64: 329-344.

KING G. \& R. PANTLING 1898. Orchids of the SikkimHimalaya. Annals of the Royal Botanic Garden, Calcutta 8: i-iii, i-iv, 1-12, 1-342, 1-2, pls. 1-133.

KRESS W.J., DEFILLIPS R.A., FARR E. \& D.Y.Y. KYI 2003. A checklist of the trees, shrubs, herbs, and climbers of Myanmar. Contribution from the United States National Herbarium 45: 1-590. https://doi.org/10.1600/ 036364404774195674

KUMAR C.S. \& K.S. MANILAL 1994. A catalogue of Indian orchids. Bishen Singh Mahendra Pal Singh, Dehra Dun.

KUMAR C.S. \& K.S. MANILAL 2004. Orchid of Kerala, India. In: MANILAL K.S. \& C.S. KUMAR (eds.), Orchid memories - a tribute to Gunnar Seidenfaden. pp. 155-254. Mentor Books, Calicut.

LI Y.L., TONG Y. \& F.W. XING 2016. DNA barcoding evaluation and its taxonomic implication in the recently evolved genus Oberonia Lindl. (Orchidaceae) in China. Frontiers in Plant Science 7: 1-9 (article 1791). https:// doi.org/10.3389/fpls.2016.01791

LINDLEY J. 1838. Sertum Orchidaceum, a wreath of the most beautiful orchidaceous flowers 2. Ridgway, London.

LINDLEY J. 1839. Miscellaneous notices. Edward's Botanical Register, New Series 2: 1-95.

LINDLEY J. 1859. Oberonia. Folia Orchidacea. An Enumeration of the known species of Orchids 1: 1-8.

LUCKSOM S.Z. 2007. The orchids of Sikkim and North East Himalaya. Privately published, Silguri.

MANILAL K.S. 1988. Flora of Silent Valley tropical rain forests of India. [no publisher given], Calicut.

MABBERLEY D.J. 2018. A portable dictionary of plants, their classification and uses. Fourth Edition. Cambridge University Press, Cambridge.

MCNEILL J. 2014. Holotype specimens and type citations: general issues. Taxon 63: 1112-1113. https://doi.org/ 10.12705/635.7

MCNEILL J. 2015. Corrigendum to 'holotype specimens and type citations: general issues' [Taxon 63: 1112 1113. 2014]. Taxon 64: 183. http://dx.doi.org/10.12705/ 641.18

MISRA S. 2007. Orchids of India - a glimpse. Bishen Singh Mahendra Pal Singh, Dehra Dun.

MITRA J.N. 1958. Flowering plants of eastern India. Volume 1-Monocotyledons. The World Press Private Ltd., Calcutta.

NAITHANI H.B. 1990. Flowering plants of India, Nepal and Bhutan: not recorded in Sir JD Hooker's Flora of British India. Surya Publications, Dehradun.
NARAYANAN M.K.R., MANUDEV K.M., SUJANAPAL P., KUMAR N.A., SIVADASAN M. \& A.H. ALFARHAN 2010. Oberonia swaminathanii sp. nov. (Orchidaceae) from Kerala, India. Nordic Journal of Botany 28: 713-715. https://doi.org/10.1111/J.17561051.2010.00822.X

NARAYANAN M.K.R., SHAJU T., SUNIL C.N., ABDUSSALAM A.K. \& V.A. JALEEL 2013. Orchids of Wayanad. Lead Books, Calicut.

NAYAR T.S., BEEGAM A.R., MOHANAN N. \& G. RAJKUMAR 2006. Flowering Plants of Kerala. Tropical Botanic Garden and Research Institute, Palode.

PRADHAN U.C. 1979. Indian orchids: guide to identification and culture. Volume 2. Privately published, Kalimpong.

PRASAD K., PRABHUKUMAR K.M. \& P. SUDHESHNA 2018. A new species of Oberonia (Orchidaceae) from Western Ghats of Kerala, India. Nordic Journal of Botany 36: e01797.1-4. https://doi.org/10.1111/njb.01797

PRIDGEON A.M., CRIBB P.J., CHASE M.W. \& F.N. RASMUSSEN (eds.) 2005. Genera orchidacearum. Volume 4. Oxford University Press, Oxford.

RAJBHANDARI K.R. 2015. A handbook of the orchids of Nepal. Government of Nepal, Ministry of Forest and Soil Conservation, Department of Plant Resources, Kathmandu.

RAO A.N. 1997. A new species and some new records of Arunachal Pradesh, India. Rheedea 7: 127-132.

RAO A.N. 2000. Oberonia kamlangensis - a new orchid from Arunachal Pradesh. Journal of Economic and Taxonomic Botany 24: 261-264.

RAO A.N. 2010. Orchid flora of Arunachal Pradesh - an update. Bulletin of Arunachal Forest Research 26: 82-110.

RASKOTI B.B. 2009. The orchids of Nepal. Raskoti \& Ale, Kathmandu.

SAKKAR P.K. 1995a. An up-to-date census of Indian orchids. Journal of Economic and Taxonomic Botany, Additional Series 11: 1-32.

SAKKAR P.K 1995b. Rare, endangered and endemic orchids in India. Journal of Economic and Taxonomic Botany, Additional Series 11: 33-47.

SALDANHA C.J \& D.H. NICOLSON 1976. Flora of Hassan district, Karnataka. Amerind Publishing Co. Pvt. Ltd., New Delhi.

SANTAPAU H. 1953. The flora of Kandhala on the Western Ghats of India. Records of the Botanical Survey of India 16: 1-396.

SANTAPAU H. 1967. The flora of Khandala. Third Edition. Manager of Publication, Delhi. 
SANTAPAU H. \& Z. KAPADIA 1960. Critical notes on the Orchidaceae of Bombay State. III. The genus Oberonia Lindl. The Journal of the Bombay Natural History Society 57: 252-269.

SANTAPAU H. \& Z. KAPADIA 1966. The orchids of Bombay. Manager of Publications, New Delhi.

SCHLECHTER, R. 1911. Die Orchideen von DeutschNeu-Guinea. Repertorium Speciarum Novarum, Regni Vegetalis, Beihefte 1: LXVI.

SEIDENFADEN G. 1968. The genus Oberonia in mainland Asia. Dansk Botanisk Arkiv 25: 1-125.

SEIDENFADEN G. 1978. Orchid genera of Thailand: VII Oberonia Lindl. and Malaxis Sol. ex Sw. Dansk Botanisk Arkiv 33: 1-91.

SEIDENFADEN G. 1992. The orchids of Indochina. Opera Botanica 114: 1-502.

SEIDENFADEN G \& J.J. WOOD 1992. The orchids of peninsular Malaysia and Singapore. Olsen \& Olsen, Fredensborg.

SEIDENFADEN G. \& T. SMITINAND 1959. The orchids of Thailand, a preliminary list, Part 1. The Siam Society, Bangkok.

SEIDENFADEN G. \& T. SMITINAND 1964. The orchids of Thailand, a preliminary list, Part 4(2). The Siam Society, Bangkok.

SERIF 2021. AffinityPhoto. Available at: https:// affinity.serif.com/en-us/photo/

SHARMA B.D., SINGH N.P., RAGHAVEN R.S. \& U.R. DESHPANDE 1984. Flora of India Series 2. Flora of Karnataka, analysis. Botanical Survey of India, Calcutta.

SINGH S.K., D.K. AGARWALA, J.S. JALAL, S.S. DAS \& A.A. MAO 2019. Orchids of India-pictorial guide.
SMITH J.J. 1913. Die Orchideen von Java, dritter Nachtrag. Bulletin du Jardin Botanique de Buitenzorg Series 2, 9: 1-130. Botanical Survey of India, Kolkata.

SRIVSTAVA R.C. 1996. Orchidaceae. In: HAJRA P.K. \& D.M. VEMA (eds.), Flora of Sikkim (Monocotyledons). Volume 1. Botanical Survey of India, Calcutta. pp. 24-120.

TANG, T. \& F.T. WANG 1951. Contributions to the knowledge of eastern asiatic Orchidaceae II. Acta Phytotaxonomica Sinica 1: 23-102.

THIERS B. (continuously updated). Index Herbariorum: a global directory of public Herbaria and associated staff. New York Botanical Garden's Virtual Herbarium. Available at: http://sweetgum.nybg.org/ih (Accessed on 13.08.2021).

TURLAND, N.J., WIERSEMA, J.H., BARRIE, F.R., GREUTER, W., HAWKSWORTH, D.L., HERENDEEN, P.S., KNAPP, S., KUSBER, W.H., LI, D.Z., MARHOLD, K., MAY, T.W., MCNEILL, J., MONRO, A.M., PRADO, J., PRICE, M.J. \& G.F. SMITH (eds.) 2018. International Code of Nomenclature for Algae, Fungi, and Plants (Shenzhen Code) adopted by the Nineteenth International Botanical Conoress Shenzhen, China, July 2017. Regnum Vegetabile 159, Volume 38. Koeltz Botanical Books, Glashütten. https://doi.org/ 10.12705/Code. 2018

TURNER I.M. 1995. A catalog of the vascular plants of Malaya. The Garden's Bulletin, Singapore 47: 347-757.

WCSP 2020. World checklist of selected plant families. Facilitated by the Royal Botanic Gardens, Kew. Available at: http://wcsp.science.kew.org/ (Accessed on 7/9/2021).

ZERENE SYSTEMS LLC 2009-2021. ZereneStacker. Available at: http://zerenesystems.com/stacker/ downloads/downloads.php 